\title{
ORganisATIONAL CONFLICT: REFLECTIONS ON MANAGING CONFLICT, IDENTITIES AND VAlUES IN a SELECTED SOUTH AfricAN ORGANISATION
}

\author{
Authors: \\ Claude-Hélène Mayer ${ }^{1}$ \\ Lynette Louw ${ }^{1}$ \\ Affiliations: \\ ${ }^{1}$ Department of \\ Management, Rhodes \\ University, South Africa \\ Correspondence to: \\ Claude-Hélène Mayer \\ e-mail: \\ claudemeyer@gmx.net

\section{Postal address:} \\ Department of \\ Management, Rhodes \\ University, PO Box 94, \\ Grahamstown, 6140, South \\ Africa
}

\section{Keywords:}

managerial values and identities; organisational conflict; South African automotive industry; organisational case study; employee identity

\section{Dates:}

Received: 27 Oct. 2008

Accepted: 29 Apr. 2009

Published: 26 June 2009

How to cite this article: Mayer, C.H., \& Louw, L. (2009). Organisational conflict: Reflections on managing conflict, identities and values in a selected South African organisation. SA Journal of Human Resource Management/SA Tydskrif vir Menslikehulpbronbestuur, 7(1), Art. \#172, 13 pages. DOI: 10.4102/sajhrm.v7i1.172

This article is available at: http://www.sajhrm.co.za

\footnotetext{
(c) 2009. The Authors. Licensee: OpenJournals Publishing. This work is licensed under the Creative Commons Attribution License.
}

\begin{abstract}
This article presents a case study on organisational conflict in a selected international organisation in the South African automotive industry to increase the contextual understanding of the topic. Data was gathered through in-depth interviews with 45 senior and middle managers in the selected international organisation at the head office and two branches in Gauteng and at one branch in KwaZulu-Natal. The data analysis was conducted through content analysis as well as triangulation of data. The research results show that managers in this industry in post-apartheid South Africa experience organisational conflicts that are associated with their managerial values and identities.
\end{abstract}

\section{INTRODUCTION}

Look, you have got two sides of conflict you have got the conflict in the company, the departmental conflict... each got its own goals...its own targets... and everything and so you have got the conflict inside. And then you have got the conflict outside. You have got the branch and the leader network and then you've got the branches that are owned by us and then you've got the conflict from the independent people, because it's their enterprise, it's their money, it's their investment. So, that is the three kind of....but any specific...I mean ... that is...is...very difficult...

(Mayer, 2008a, p. 374)

The complexity, uncertainty and conflict potential of the early 21st-century business environment - as described in the opening citation - requires that fundamental transformation take place in organisational management, thinking and practices (Voelpel, Leibold \& Tekie, 2006). Due to increasing trends of managers transcending geographic, economic and socio-cultural boundaries, conflict and the management thereof, particularly in international organisations, need further attention (Kriesberg, 2003a; Mayer \& Louw, 2007). These trends often impact on managers and their daily work routine and are experienced by many of them as being conflictive and difficult to deal with (Mayer, 2008a, p. 374). As shown in the quote above, conflict in organisational contexts has diverse aspects, including conflict within the network of headquarters, branches and dealerships, referring to intra- and interorganisational aspects.

In the following, the literature on human resource management with regard to organisational conflict, identities and values, and selected aspects of their interrelationship will be reviewed. Therefore, it is important to draw attention to the interconnectivity of these complexities and their management.

\section{Organisational conflict and its management}

Conflict research, particularly since the 1970s, has been embedded in (social) constructivist theories, which view reality as a construct created by the mutual inter-relationships between individuals and the environment (Applefield, Huber \& Moallem, 2000; Coy \& Woehrle, 2000; Demmers, 2006; Lederach, 2000). In these terms, conflict can be defined as 'a feeling, a disagreement, a real or perceived incompatibility of interests, inconsistent worldviews, or a set of behaviours' (Mayer, 2000, p. 3). At the same time, 'conflict is a psycho-social process' (Northrup, 1989, p. 54), which includes social interactions and is shaped by individual and cultural meanings (Augsburger, 1992; Avruch, 1998; Lederach, 2000). These cultural meanings are constructed by including 'perceptions, interpretations, expressions and intentions' (Lederach, 1996, p. 9), which result in conflict. Thus, 'conflict situations are those unique episodes when we explicitly recognize the existence of multiple realities and negotiate the creation of a common meaning' (Lederach, 1988, p. 39). This means that, in conflict situations, people experience the relativity of realities while simultaneously negotiating and creating their shared meaning. Conflict is linked to the inner processes of people and their relationship with the environment and is, therefore, an inevitable part of organisational life (Jones \& George, 2003).

According to studies done by Pondy (1992), organisations are riddled by conflict, and the need for conflict analysis and conflict management in organisations is, therefore, essential. The potential for conflict in internationally acting organisations continues to grow, both through globalisation trends and (re-)structuring processes in international business. In parallel, scientific research on conflict and the management thereof has continued worldwide (Coleman, 2003) and has further attracted the interest of management scientists in analysing organisational and managerial conflict scenarios (Francis, 2003; Pondy, 1992; Rahim, 2001; 2002). This has rarely taken place in the Southern African organisational context (Mayer, 2008a).

A broad variety of conflict research has been conducted concerning special aspects of 'types of conflict' (Jehn, 1997), 'sources of conflict' (Gobeli, Koening \& Bechinger, 2003) or 'conflict management styles' (Antonioni, 1998). However, these aspects and categories are not relevant for this case study.

A wide range of theories and practical tools has been developed for the management of conflict, both internationally (Miall, Ramsbotham \& Woodhouse, 2000) and by the South African scientific community (Shonhiwa, 2006). Conflict management is the art of appropriate intervention to achieve conflict settlement (Nye, 2005). It is the positive and constructive management of difference and 
divergence. Rather than advocating methods for removing conflict, conflict management

addresses the more realistic question of managing conflict, namely, how to deal with it in a constructive way; how to bring opposing sides together in a cooperative process; and how to design a practical, achievable and cooperative system for the constructive management of difference.

(Ghai, Bloomfield \& Reilly, 1998, p. 18)

Accordingly, conflict management does not necessarily imply the avoidance, reduction or termination of conflict. Rather it helps in the design of effective strategies to both ,minimise dysfunctions and enhance the constructive functions of conflict ${ }^{\prime}$ thereby enhancing learning and effectiveness (Rahim, 2002, p. 208).

Organisational conflict can result in strong intra- and interpersonal distress, distraction from work, difficulties in decision making and interpersonal contact, and has a negative affect on effectiveness, productivity and creativity (Cowan, 1995). Organisational conflict therefore is at the centre of theoretic and practical discourses on the international management of human resources (Harris, Brewster \& Sparrow, 2003; Hiltrop \& Partner, 1996; Sparrow \& Hiltrop, 1997), as well as that of organisational behaviour (Garcia-Prieto, Bellard \& Schneider, 2003; Mullins, 2007).

Relationships and communication processes, as well as identity and value aspects of the managers in the organisation, are highly influenced by conflict and its management. The inter-connectivity of these aspects in the setting of international organisations in South Africa is highly complex and requires further attention, especially as the international South African automotive industry is driven by the 'double transition' (Webster \& Adler, 1999) of the country: on the one hand, international co-operation, such as joint ventures driven by globalisation, has changed the way business is conducted in South Africa (Bornman, 2003). On the other hand, the internal socio-political transition of South Africa from an apartheid state to a new democracy subsequent to 1994 influenced globalisation and management trends, as well as conflict and the management thereof in organisations (Webster \& Adler, 1999)

Because of the recent trends in South Africa, which have been described, managing diversity has become a relevant topic in the area of human resource management and international behaviour (Horwitz, Bowmaker-Falconer \& Searll, 1996; Human, 1996; Wood \& Mellahi, 2001). Cultural diversity not only encompasses differences in visible characteristics such as race, gender and ethnicity, but also includes differences that are not necessarily visible, such as religion, professional background and sexual preference (Francesco \& Gold, 2005). It can be described as a mosaic in which all component pieces form an image (Kandola, 1995) and is understood as possessing an acute awareness of characteristics common to cultures, races, genders and ages, while at the same time managing staff members as individuals (Overman, 1991). Diversity includes value diversity (Fryzel, 2004; Mujtaba, 2006), which can be distinguished into different kinds of values, such as business, individual, corporate or organisational values (De Anca \& Vega, 2006).

However, there is a gap in the literature on the inter-linkage of conflict, values and identities in the international South African organisational conflict. This case study wants to begin to fill this void by addressing these issues through a qualitative case study.

\section{Identity in organisational conflict}

Interdisciplinary, identity and intra-personal processes comprise popular research topics that have, during the past decades, drawn interest from the management sciences (Albert, Ashforth \& Dutton, 2000; Gioia, Schultz \& Corley, 2002; Hatch \& Schulz, 2002; Pratt \& Rafaeli, 1997; Whetten \& Godfrey, 1998). In the fields of management and organisational studies in particular, identity is viewed as an overall topic that interlinks individual and organisational management levels in organisations (Humphreys \& Brown, 2002). At the same time, both managers and organisations are constructed by identities, and (re-) construct these with regard to self and others across managerial and organisational levels.

According to various authors (Alvesson, 2000; Dutton, Dukerich \& Harquail, 1994), the increasing complexity of social patterns and social fragmentation in organisations has increased the importance of inter-related identity constructions, leading to a sense of organisational belonging and organisational identity. This increasing multiplicity of organisational patterns results in the individual identity being viewed as a kind of 'patchwork identity' (Keupp, 1988, p. 425), which forms the depending equivalent patterns to the social and organisational multiplicity. Such 'patchwork identity' (Keupp, 1988, p. 425), carrying multiple and diverse identity aspects, can lead either to positive effects, such as the creation of synergies and Kreativitätsspielräume (creativity spaces) (Keupp, 1994, 1997), or the creation of conflict and tension (Rahim, 2002). At the same time, conflict is always created through aspects of identity (Lederach, 2005; Mayer 2005) and can, therefore, be defined as a 'psycho-social process' (Northrup, 1989, p. 54)

Individual identities can be constructed from a variety of identity aspects that evolve from inner processes and selfascriptions, such as being pedantic, self-convinced and ambitious. Conversely, identity aspects can derive from social identities and group membership, such as culture, race, gender, nationality and/or profession. Managerial identities, therefore, are bound to inner processes and to both social interaction and communication (Lindgren \& Wåhlin, 2001). In this article it is argued that identities cannot simply be reduced to certain stable institutionalised aspects such as race, gender or profession, but should rather be seen as a dynamic process of (re-)construction of self-ascriptions and social identities that are flexible in reconstruction and contextualisation.

In the management sciences, however, identity aspects and their dynamics in relationship to conflict need to be assessed and evaluated further to both understand and manage the origins of conflict in organisations, as well as to develop tools for intra- and inter-personal conflict management (Mayer, 2008b).

\section{Values in organisational conflict}

The challenge for South African managers is to find creative solutions for integrating diversity characteristics, identity aspects and value differences, while simultaneously overcoming deeply entrenched discriminatory practices and social division created by valuing people according to their cultures (Jackson, 2002). There is evidence that diversity, if not managed well, can contribute to an increase in conflict (Church, 1995). In this context, the management of conflict has emerged as a vital issue in human resource management. Diversity and conflict management, therefore, not only need to be conceptually integrated to raise consciousness and awareness across managerial levels (Horwitz et al., 1996), but should further be contextualised within the organisation to create a better understanding of managers within an organisation.

Conflict and ambiguity may arise from situations in which beliefs and values work at cross purposes with one another in groups and organisations (Martin, 2002). Research on value orientations has recently intensified, with an increasing focus on the African region (Schwartz \& Bardi, 2001; Schwartz et al., 2001). Sub-Saharan Africa is, however, still under-represented in (cross-cultural) value research, even though values and value conflicts have played a considerable role in different sectors in South Africa, both throughout its history and at present (Mayer \& Louw, 2007). 
Values and value orientations are patterns of thoughts and actions (Kluckhohn \& Stroedbeck, 1961) and are important to most members of a community or group. The consensus on values themselves is subject to change over time, and group members are principally able to adopt the values of others (Burton, 1990). Values are often un-reflected and unconscious until conflicts occur and the conflicting parties realise that their conflict derives from differences in patterns of thought and action. Contradictory or competing values can cause intra- and interpersonal conflicts (Coy \& Woehrle, 2000; Kriesberg, 2003a; 2003b; 2003c) that are context and situation bound.

Booysen (in Nel et al., 2004) is of the opinion, however, that there is a definite lack of cultural awareness - in a broad sense - in organisations in South Africa, and that only $24 \%$ of organisations have implemented diversity-management programmes. He further states that new recruits are expected to assimilate the organisational culture and that resistance to change in organisations is expected from members of all cultural groups. An urgent need therefore exists to assess and understand organisational conflict and values as part of diversity so as to manage them effectively. Organisational conflict and the negotiation of values are often inter-related (Berkel, 2005; Wallace, Hunt \& Richards, 1999), particularly with regard to organisational processes (Gandal, Roccas, Sagiv \& Wrzesniewski, 2005; Smith, Peterson \& Schwartz, 2002) and to the organisational culture, which plays a major role in managing organisational conflicts constructively (Pool, 2000).

The discourse on international human resource management - including aspects of conflict, diversity, identity and values and their management - is growing (Kamoche, 1997; 2002). Challenges can definitely be defined in areas of constructing organisational cultures that integrate diverse managerial and organisational aspects (Thomas \& Bendixen, 2000). Jackson (1999) particularly emphasises that organisations in South Africa need to focus on issues concerning the value attached to people in organisations, as this has not yet been addressed properly.

The contribution of this paper is toward increasing the clarity and interdisciplinary understanding of these complexities and to provide recommendations for managing organisational conflict, identity and values in international organisations acting in the South African context. This discourse imparts new stimuli for the scientific debate, as well as for managers, practitioners and consultants active in this field.

The purpose of this paper is to approach the issue of conflict, identity and values, and their inter-connection, in a selected organisation to improve the understanding of human resource management in this specific South African organisational context by addressing perceptions on values and identities of managers from - as far as possible - an emic perspective. In addition, it presents selected qualitative research results on organisational conflict from a case study in the described setting.

The aim of this paper is to answer the following research questions in investigating such managerial perspectives:

- Which organisational conflicts are perceived by managers in the selected organisation in the international South African automotive industry?

- Which identity aspects do the managers regard as being important in organisational conflict?

- Which value orientations, according to the managers, play a role in these organisational conflicts?

- How do the managers resolve these organisational conflicts?

These research questions can only lead to specific answers referring to the selected organisation, and are not necessarily generalisable. However, they can serve as new stimuli in the discourse on the abovementioned topics.
The research design and the selected results will be discussed next, followed by a discussion of the results and recommendations.

\section{RESEARCH DESIGN}

This case study is based on the postmodernist premise that there is no single true reality and that there is no absolute truth (Becvar \& Becvar, 2006). This premise asserts that human beings inhabit different realities that are socially constituted and that may, therefore, vary quite dramatically across cultures, time and context (Gonzalez et al., 1994); and that multiple selves are socially constructed in the context of increasingly varied and constantly changing relationships (Becvar \& Becvar, 2006).

The organisational case study presents managerial perspectives on conflict, identities and values, and views them as one option to (re-)construct the contextual truth referring to these topics. It can therefore only be one piece within a 'mosaic' of reality constructs.

\section{Research approach}

Given the qualitative nature of this research, the phenomenological and interpretative paradigms were considered to be the most relevant approaches (Collis \& Hussey, 2003). Within these paradigms, the theoretical and methodological approaches used are found in both the epistemological tradition of constructivism (Berger \& Luckmann, 2000) and interpretative hermeneutics (Habermas, 1999). Various theoretical stances reflect a postmodern epistemology and can be grouped under terms such as constructivism or social constructivism, which share the notion of multiple realities. Here, constructivism is used as an umbrella term for both constructivism and social constructivism (McLeod, 1996) and is generally defined as postulating the objective world as a construct of social interaction or, alternatively, as a process of the observed and the observer, the last giving meaning to what is observed (Jonassen, 1991). Constructivism, therefore, implies that all stories or interpretations are equally valid and that there is no single truth or interpretation (Dickerson \& Zimmerman, 1996). This means that the research results from this organisational case study need to be (re-)confirmed through parallel case studies conducted under different contextual parameters.

\section{Research strategy}

While quantitative research is often based on analytical empiricism, with a strong emphasis on objectivity, qualitative research focuses on gaining a deeper understanding of the research issue (Cheldelin, Druckman \& Fast, 2003), deep data and 'thick descriptions' (Geertz, 1987). Sveningsson and Alvesson $(2003$, p. 1164) assert that few studies address the understanding of specific processes and situations of identity construction in and around work and organizations'. In order to 'share an interest in personal views and circumstances' and to gain an understanding of processes and situations of identity in the selected organisation, a single-case explanatory study approach was used (Stake, 2005, p. 448). This organisational case study approach was used because of its focus on collecting and understanding the perspectives of managers in a selected organisation on the abovementioned issues within this context, which provides - with its organisational cultures and structure a frame for conflicts, their management and their interpretation. Using an organisational case study turned out to be a good research strategy, because the managers of the organisation reflected a broad and diverse workforce that reflected aspects of the South African society. At the same time, this organisation is a valuable example of a successful international organisation in which the managers succeed in managing conflicts, identities and values across cultures and nations. Finally, the organisation acted as an adequate platform for exploring the issue and for the process of the research (see below). This choice of research strategy led - as expected - to a broad variety of data, as shown in the presentation of selected results. 
This organisational case study approach was used to assess the association between organisational conflict and the managerial values and identity constructions of senior and middle managers in the selected organisation in conflict situations. The assessment was done using in-depth interviews. The interviews were guided by predetermined research questions, as stated previously, which focused on the subjective elements of the managers' perceptions, narrations and interpretations relating to the selected topics according to four levels of text reconstruction (Ricoeur, 1979; Wolff, 2000), which are explained in the section on data analysis. The results cannot be generalised, but provide in-depth insight into the described contexts and could possibly be replicated in other organisations in South Africa.

As stated previously, the aim of this study was to gain deeper understanding of the subject described above in the South African automotive context, as well as to formulate appropriate recommendations for theorists and practitioners working in similar fields. Depth in the understanding of the reality was achieved in that the researcher and managers had a mutual relationship. The research results were obtained from the interdependent relationship between the 'issue of research' and the 'process of research' (Stellrecht, 1993, p. 36). In this study, the issue of research pertained to identity and values in conflict and its management, while the process of research encompassed the identification of keywords with regard to organisational conflict, values and identity and the management thereof, hermeneutical reconstruction and the presentation and interpretation of the mentioned concepts. The 'issue of research' was narrated in the interviews and was highly dependent on the trustful relationship between the researcher and the managers, particularly referring to the challenging core issues of this research. The 'process of research' included the analysis and evaluation of the data. By interlinking the issue and the process of research, the research results were constructed based on the inter-personal relationship.

\section{Research method}

An explanatory case study was used to understand and explain organisational conflict and related managerial values and identity aspects. The research method used in this organisational case study approach is explained in this section by considering the research setting, data collection and data analysis methods.

\section{Research setting}

The German organisation used for this case study operates in 120 countries worldwide and belongs to one of Europe's leading engineering groups. As a technical leader in the automotive industry it is ranked among the top three suppliers in each of its worldwide markets. The organisation employs 58000 people

TABLE 1

Guiding principles of organisation

\begin{tabular}{ll}
\hline SHAREHOLDERS & GUIDING PRINCIPLES \\
\hline Customers & $\begin{array}{l}\text { Value for customers } \\
\text { Listen to customers and meet their requirements } \\
\text { Measurement according to success with products and } \\
\text { services }\end{array}$ \\
& $\begin{array}{l}\text { Set attractive yield targets } \\
\text { Expand leading market position in core areas of activity } \\
\text { Investors }\end{array}$ \\
$\begin{array}{l}\text { Ensure tomorrow's success with today's research and } \\
\text { development }\end{array}$ \\
Employees & $\begin{array}{l}\text { Provide a modern management culture } \\
\text { Promote knowledge and experience among staff members } \\
\text { as molieve in fairness, tolerance and equal opportunity }\end{array}$ \\
Society & $\begin{array}{l}\text { Ensure social acceptance } \\
\text { Guided by principles of sustained yield } \\
\text { Respect dignity of human beings }\end{array}$ \\
\hline
\end{tabular}

Source: Author's own construction, adapted from Organizational Paper, 2006a:16 worldwide in its five core areas of activity, namely Commercial Vehicles, Industrial Services, Printing Systems, Diesel Engines and Turbomachines (Organizational Paper, 2006a). One of its largest sales regions is Southern Africa (Organizational Paper, 2006a) where the organisation consists of a head office, Parts Division and Bus and Coach Manufacturing plant in Gauteng, as well as a Chassis Assembly Plant in KwaZulu-Natal (Organizational Paper, 2006b). Central to this research were the key issues of guiding organisational principles and policies. The organisation has adopted guiding principles pertaining to its customers, investors, employees and the society within which it operates (Organizational Paper, 2006b), as shown in Table 1.

These guiding principles are objectives for the corporate culture of the organisation. The relevant diversity-related and conflicthandling policies, such as the Employment Equity, Affirmative Action and Conflict Management Policies of the organisation, are based on these principles, as well as others, and are in place and well managed (Organizational Paper, 2002a; 2002b).

The selection of this organisation for the case study was based on the following reasons:

- global and regional business involvement and standing, as discussed previously;

- diversity, due to the different plants and offices in various regions in South Africa;

- diversity-related and conflict-handling policies are in place and well managed;

- international management profile; and

- permissible access to the organisation.

\section{Entrée and establishing researcher roles}

The entrée of the researcher into the physical field of research was prepared through establishing contacts and meetings with key persons in the organisation at the German and South African headquarters. These meetings included discussions on the topic, and on the content and the process of the research, whilst building a trustful relationship. Managers were identified and asked by the human resource office to participate in the research. They then received information on the research project.

The role of researcher was constructed through the discussions with the key persons in the organisation. The role was defined as being an 'external, independent researcher' who aimed to understand the abovementioned issues from the point of view of the organisation and its managers. This role could be maintained throughout the project, even though a long and intensive period of time was spent in the organisation.

Permission to undertake the research was granted by the human resource offices of the German and South African headquarters and by the branches themselves. Each manager agreed to participate voluntarily. Permission was obtained from the Board, the HR office and the managers after discussions and agreements on the content and process of the research. Permission to conduct the research was also given by the ethics committee of the university involved.

Confidentiality was guaranteed by the researcher and maintained throughout the research process and when the data was published. The names and positions of the managers were therefore not linked with the content of the data to ensure anonymity and confidentiality.

\section{Sampling}

This sample was representative of the senior and middle management levels at the selected organisation's head office and three of its branches. The sample comprised managers from South Africa, Germany, the Netherlands, England and Zimbabwe respectively. A total of 95 senior and middle managers were approached to participate in the research and 45 managers 
(37 male and eight female) eventually agreed to participate. In terms of nationality, 37 managers were South African (SA); three were German; four managers each hailed from the Netherlands, Zimbabwe and England; and one manager neglected to record nationality. Of the 45 managers, 31 worked at the head office (Gauteng), three worked at branch I (Gauteng), four worked at branch II (Gauteng), six worked at branch III (KwaZulu-Natal) and one manager neglected to record a place of work.

\section{Data-collection methods}

Triangulation of data was used in this organisational case study by conducting in-depth interviews and reviewing secondary literature and the internal documents of the organisation.

An open-ended questionnaire was constructed as the main data-collection method for this research. Seven interview questions were asked in a face-to-face interview to stimulate conversation. The questions referred to conflicts experienced in the organisation, conflict management, actions to resolve conflict, identity, value orientations, management style, need for improvement of the organisation and (future) conflictintervention strategies. Aspects of validity and reliability were of importance in this study.

Four major concepts - conformability, credibility, transferability, and trustworthiness - were defined as criteria for judging the qualitative research. Johnson (1997) supports the approach that constructivism may facilitate the aim of qualitative research - which is fundamental to this research - to create a deeper understanding of the research objective with regard to changing multiple-reality constructions (Hipps, 1993). Parallel to the interviews, organisational documents and secondary literature were analysed to guarantee triangulation of the data.

\section{Recording of data}

The managers' in-depth interviews were recorded in full to ensure precise transcription. The transcripts were viewed as selective constructions that reproduced aspects of the conversation and which were transcribed, according to Von Steinke (2000, p. 327), in a 'manageable' way, which is 'simple to write, easy to read, easy to learn and to interpret'. This means that standard orthography was used throughout the transcription processes: the transcription procedure focused mainly on the verbal aspects of the communication, in the interest of analysis and evaluation controlled by factual words. Analytical data evaluation was included (as described below under Data analysis, Level 4), subsequent to the texts being transcribed.

\section{Data analysis}

After the data had been gathered, it was collected and analysed according to four levels of text reconstruction (Ricoeur, 1979; Wolff, 2000):

- Level 1: The manager experienced a (trans-cultural) conflict situation and specific identity and value aspects.

- Level 2: The manager narrated the conflict identity aspects and values during the interview.

- Level 3: The researcher transcribed the interview and categorised this transcribed text through content and keyword analyses.

- Level 4: The researcher interpreted the categorised text through content analysis (Mayring, 2003), based on a systematic approach to accidental perceptions. Key terms are defined as words that occupy key positions in the text through the import of their content, their significance in the text structure, and conception or repetition or other emphasis. This culminates in the construction of categories; hence, content analysis serves as a technique of research that leads to conclusions that can be generalised (Kromrey, 1998).
Data analysis was conducted according to the five-step process of Terre Blanche, Durrheim and Kelly (2006: 322-326): Step 1: Familiarisation and immersion, Step 2: Inducing themes, Step 3: Coding, Step 4: Elaboration and Step 5: Interpretation and checking, to ensure a transparent process of data analysis and reconstruction.

However, in reality, interpretative analysis rarely proceeds in as orderly a manner as may be suggested by our step-wise presentation (Terre Blanche et al., 2006, p. 322-326). Following these steps in data analysis enhances the 'thick description' (Geertz, 1973).

The text has been (re-)constructed by content analysis using categorisation (e.g. as organisational conflicts) and coding (e.g. with regard to values and identities), which leads to elaboration and interpretation. Content analysis ${ }^{1}$ comprises a subjective process between the text and the person coding the text: 'Verifying the reliability of content analysis is primarily done by inter-individual and intra-individual verification' (Yin, 2002, p. $45)$, as in this study. Objectivity in analysis is guided by intersubjective validation, such as adhering to particular rules and regulations and/or verifying that the same (or similar) results have been attained by different researchers. In this study, the coding of the text and its analysis and re-categorisation through content analysis are considered in this way. This process includes the 'constant comparison' method (Strauss, 1987, p. 12) that is used to look for similarities and differences in the data. From this process, the researcher identifies underlying uniformities in the indicators or incidents (actions, events, perspectives) and produces a coded category or concept. These categories are compared with one another and with new incidents to sharpen the definition of the concept and to look for possible new categories. Categories are clustered together to form themes, which are used to describe the phenomena.

\section{Strategies to ensure data quality and reporting}

Strategies that were employed to ensure data quality were based on specific criteria. The criteria to ensure qualitative data research include confirmability, credibility, transferability and trustworthiness for this organisational case study. Relevant strategies of qualitative data collection, analysis and interpretation were used.

This research is based on research ethics that ensure the quality of data with regard to ethical guidelines, which have been implemented in the research and which have been accepted by the research ethics commitment of the university involved as well as by the organisation studied. Ethical considerations include, among others, the respect accorded to and the rights of the managers, the creation of informed consent, confidentiality and anonymity, and transparency (Mayer, 2008a, p. 111).

Data was stored on a voice recorder, transcribed and again stored on electronic equipment. ATLAS.ti software was used to analyse the data by content analyses.

In the following sections, the results will be reported by presenting selected results in a qualitative reporting style according to the research methods used in the research for this case study. ${ }^{2}$ Organisational conflict, identity and value concepts will be introduced by describing the conflict scenarios and contributing aspects that were narrated by the interviewees.

In the following section, selected data on organisational conflict are presented by giving short summaries of the conflict stories.

1.For a more detailed description of content analysis with regard to the data, please see Mayer (2008a: 117ff).

2.Interview narrations were coded according to the interviewees and conflict stories narrated: P7:2 means, for example, interview person number 7 , conflict story number 2 . 
These summaries are followed by subsections in which the conflict is interpreted, referring to the values and identity of the managers.

\section{RESULTS}

The research results presented here focus on managerial perspectives on organisational conflict; identity and values involved in these experienced and narrated conflicts; and the management thereof in the selected international organisation. The ways in which managers were challenged by the conflict that occurred, and how they met these challenges in a diverse organisational context, will be discussed. Finally, recommendations for international human resource management in the context of the South African automotive industry will be made.

The main results from this case study indicate that managers from diverse backgrounds experience organisational conflict mainly when values are not considered adequately and identity concepts clash. Conflict experiences were related primarily to five conflict categories, namely: Communication and Treatment; Position and Competition; Organisation; Race and Gender; and No Conflicts. Selected conflicts from the category Organisation will be presented in the following section, specifically with regard to underlying identity and value concepts and attempts to manage such conflicts. These are focused on because the category Organisation provides a deep insight into the value and identity concepts of managers in the described context.

\section{Organisational conflict}

This conflict category mainly includes conflicts which provide a deeper understanding of the structure and function of the organisation. Organisational conflicts were only narrated by managers who defined themselves as white. All instances of organisational conflict, except one (P7:2), were narrated by male managers. This category is the only one in which the managers did not connect the conflict to racial or cultural belonging, but only to the structure and operational aspects of the organisation. A summary of the conflicts reported and biographical data is presented in Table 2 . This is followed by a discussion of the results pertaining to the selected organisational conflicts. P3:1 Warranty: P3 experienced the issue of warranties as very conflicting in the organisation. He was in the position to decide on the 'validity of warranties'. This could be difficult, especially when colleagues, particularly salesmen, had given the customers 'incorrect information about the warranty', which then forced P3 into rejecting the customers' claims. He would often be accused of dishonesty, even if the warranty conditions were set by the organisation and not by him personally. Therefore, his nickname in the organisation was 'Mr No'. This name made him feel very uncomfortable. Conflicts relating to warranties, therefore, often not only entailed conflicts with customers, but also entailed a deeper conflicting aspect, namely that of the 'information policy of the organisation and the question of corporate identity'.

The conflict experienced by P3 touched on the core values of honesty, transparency and truth which he claimed for himself and for the organisation and its employees. These values, however, were not linked to individual identity, but rather to the organisational system or work-related organisational identity aspects, which he viewed as being the base of the organisation's corporate identity. These values provided objectivity in the organisation and all persons involved. P3 felt strengthened by these common values, which led to his strong-mindedness as a manager.

Transparency and truth as core values - leading to direct and honest communication and strong-mindedness - helped P3 solve his conflicts in the organisation. In his opinion, the management of conflict included 'mediation' and 'exchange of interpretation with regard to truth'. He claimed that 'warranties helped follow the truth'. He was prepared to give his subordinates 100 per cent support and assistance, at a medium-distance level, whilst keeping his focus on power and success.

P4:1 Training in workshops: P4 wanted to offer training at the headquarters' training centres, but experienced conflict because the workshop managers wanted the training to be conducted in their workshops, mainly to 'save money and time'. In his opinion, the workshop owners did not have enough 'interest in education' and were 'not flexible' enough to send their employees for training.

This conflict touched on P4's value of flexibility. He did not feel personally hurt by the conflict, but felt that his position as a manager gave him the authority to lead and decide. He felt that

Conflicts experienced and related biographical data

\begin{tabular}{|c|c|c|c|c|c|c|c|}
\hline \multirow[b]{2}{*}{$\begin{array}{l}\text { ORGANISATIONAL } \\
\text { CONFLICT EXPERIENCED }\end{array}$} & \multirow[b]{2}{*}{ RESPONDENT } & \multicolumn{6}{|c|}{ BIOGRAPHICAL DATA PER RESPONDENT } \\
\hline & & GROUP & $\begin{array}{l}\text { MOTHER } \\
\text { TONGUE }\end{array}$ & $\begin{array}{l}\text { OCCURRENCE } \\
\text { OF CONFLICT }\end{array}$ & GENDER & AGE GROUP & CITIZENSHIP \\
\hline Warranty & P3:1 & White & Afrikaans & Headquarters & Male & $40-49$ years & SA \\
\hline Training in workshops & $\mathrm{P} 4: 1$ & White & English & Headquarters & Male & $40-49$ years & SA \\
\hline Departmental conflict & $\mathrm{P} 7: 2$ & White & Afrikaans & Headquarters & Female & $30-39$ years & SA \\
\hline Mentality of mistrust & $\mathrm{P} 9: 1$ & White & Dutch & Headquarters & Male & $50-59$ years & The Netherlands \\
\hline Conflict with union & $\mathrm{P} 13: 2$ & White & English & Headquarters & Male & $30-39$ years & SA \\
\hline $\begin{array}{l}\text { Operational conflict with staff } \\
\text { members }\end{array}$ & $\mathrm{P} 19$ & White & Afrikaans & Headquarters & Male & $50-59$ years & SA \\
\hline Conflict with a branch & P20 & White & English & Headquarters & Male & $20-29$ years & SA \\
\hline Work time company rules & P32 & White & Afrikaans & Branch III & Male & $30-39$ years & SA \\
\hline $\begin{array}{l}\text { German or local contract } \\
\text { in SA }\end{array}$ & P41 & White & German & Branch I & Male & $30-39$ years & Germany \\
\hline
\end{tabular}

Source: Author's own construction 
he had developed a 'strong, conservative identity' concerning his managerial position in the organisation, which helped him to cope with 'personal injuries' that might have been caused by conflict. He did not view discussions and arguments as desirable options for conflict resolution. He therefore first analysed all the available information to gain an 'objective overview on the issue' to obtain clarity on how to proceed.

P4 deemed objectivity in conflict to be 'successful and strong' in a managerial position. He was able to compromise by considering the interests of the other parties and by engaging in 'interactive, two-way communication', whilst still adhering to the rules and procedures of the organisation. He preferred to submit the issue to the objective formal disciplinary system in the 'event that such rules were not respected'

P7:2 Departmental conflict: P7 generally felt 'over-controlled by the junior manager' in her department and experienced neither co-operation nor sharing of information. When she explained herself she experienced negative comment from senior management and did not receive any support:

Direct conflict, yes, ahm...one manager towards me and that is one of the reason why I am leaving, permanently shouting, ahm, not open for an embetterment of a working environment, refusing to work in a more logical way, I am sorry, I can't work like that. Resolution? Get another job. I have discussed it in top management board in front of him on two situations, about his behaviour and his mannerism and this board has chosen that being shouting at (by) people is correct. Talking bad about people is correct.

She felt that her junior manager did not follow the 'ethical guidelines of the organisation', because whilst he was very friendly to her he also 'talked negatively about her behind her back'. She described him as 'discriminative and racist'. P7 further felt unfairly treated as a result of the high work pressure placed on her: She worked daily until 10 pm, whereas her superior left at $5 \mathrm{pm}$. She defined her experienced conflicts as gender based, as she suspected that the junior manager would have 'dismissed her to replace her with a male colleague' if he had the power. Her managerial values of racial equality, gender equality and respect, as well as adequate conduct and ruling by senior managers, were not considered. She felt that her identity was consequently weakened by the conflict and she felt intimidated and hesitant to speak out about it.

P9:1 Mentality of mistrust: 99 had experienced many instances of conflict, ranging from conflict with the managing director to conflict based on the organisation's mentality, which he described as 'mistrustful and over-controlled'. He felt that the conflict recounted had 'shaken his personal identity'. He particularly experienced mistrust with regard to the relationship between the German and South African headquarters, mainly due to miscommunication.

He missed the value of transparency and open communication within the whole organisation, as well as the building of trust through social networking, sharing of information and 'opening up of files'. His vision for the organisation was one of more open and trustful communication, direct work approaches and open-door policies. Sharing information was his key to trustful relationships, rather than that of following hidden agendas.

P13:2 Conflict with union: The core conflict presented by P13 dealt with union activities and the organisation. He described the staff as 'politically active' in a certain trade union, thereby 'polarising themselves and the managers'. The blue-collar workers were demanding higher wages and increased benefits and emphasising their demands with go-slow work methods. He believed that cultural issues and a fight over distribution between white management and black workers underpinned the strikes.

P13's identity seemed to be very strong; he understood his colleagues and felt that his identity was 'guided by diplomacy'.
He was, however, convinced that an organisation's highest value was in working in harmony. His value of harmony was accompanied by a mature sense of collaboration: mature in the sense of not standing against each other due to incompatible interests, but rather joining together and pursuing higher common goals. P13, therefore, emphasised the valuing of and paying respect to one another. He stressed honesty, but admitted that some powers could, for certain periods, undermine his ideas of peaceful harmony and freedom to achieve the organisational targets. With regard to the value of harmony, he managed his conflicts through team discussions and mediation, guided by his identity: 'I am not trained to do that, but what I am trained in is to tell you what is in my heart. So, I will tell you that.'

P19: Operational conflict with staff members: P19 described the situation as an operational conflict that had emerged between staff and management. In general terms, P19 reported that staff members refused to 'carry out work orders as a result of either lack of commitment or work pressure'. He stated that conflict was a 'normal operational thing'. His conflicts concerned the different interests of managers and staff; a lack of commitment; and the achievement of good results for the organisation. To him, conflict was limited and manageable, because he was leading by exerting strict control and displaying the correct behaviour. He also felt that his identity was driven by 'strictness and control'.

P20: Conflict with a branch: P20 experienced severe conflict when he made a mistake with the pricing of some spare parts whilst working at the headquarters. Salesmen at a branch immediately sold the parts at these very low prices, although they should have perceived that a pricing mistake had been made. P20 felt abused by these colleagues, as he felt they were supporting their customers at the expense of a superior: 'We should work together and not against each other in the company.'

P20 experienced a lack of cooperation, an abuse of weakness and a break of confidence with regard to this branch when he made the pricing mistake. His values of truth and trustful networking seemed undermined. P20 experienced this conflict as a real threat to his identity, because he felt his identity was based on truth and harmony. He partially experienced the conflict on a personal level, even though he realised he should not take his organisational conflict personally. The values of trust and cooperation should, according to P20, be organisational values, rather than the values of single individuals. For him, the conflict was not managed, but he would have appreciated a pricing system that would not have allowed such mistakes.

P32: Work time company rules: The conflict reported by P32 involved a staff member who refused to 'follow the company rules and regulations regarding working hours'. It was common practice in the company that, in the event of a public holiday falling on a Monday, the working hours would be prolonged for one hour on the Friday preceding the public holiday. One staff member applied for overtime payment for this hour and waged a strike in protest against the rules. P32 tried to solve the conflict through discussion, but was severely 'offended in the process'. The staff member complained of being 'exploited by a capitalistic company'.

The conflict included four keywords: company, work, rules and time. These words represented certain values that the managers had to abide by. P32 supported a corporate identity within the company based on these values. According to him, the staff member had acted irresponsibly, as the staff member valued his leisure time more than corporate company rules and procedures. P32, therefore, considered the company values endangered. The interviewee wanted to avoid negotiating about the organisational rules and values. He felt that his direct and clear communication influenced his identity strongly. The challenges arising from the conflict in which he had been engaged were so strong that P32 felt disrespected and personally hurt. He referred the conflict to a disciplinary hearing and regained personal integrity. 
P41: German or local contract in SA: P41 reported an intra-personal conflict. He had moved from Germany to South Africa, married a South African citizen and, after six years, had to decide whether he wanted to remain in the South African company and receive a local contract (until then he was working as an expatriate) or return to Germany. He decided to remain in South Africa, but felt angry about 'being forced to make his decision quickly'. He further complained about changing management structures and a 'lack of the right people in the organisation'. Finally, P41 was very unhappy to receive a South African salary, but continued to obey the rules and procedures of the organisation. Generally, he felt that his concept of identity had been shaken terribly by the conflicting changes and that he had lost the 'dedication to his job'.

\section{DISCUSSION}

The purpose of this paper was to assess managerial perspectives and to gain deeper understanding of organisational conflict with regard to values and identities, and the management thereof, in a selected international South African organisation in the automotive industry.

\section{Managing organisational conflicts}

Some authors (e.g. Northrup, 1989, p. 55ff) view organisational conflict as 'psycho-social processes' that are constructed by managers through their external realities and their internal perceptions and in relationship to aspects of their values and identity (Demmers, 2006; Lederach, 2000; Rahim, 2002). This study supports this assumption.

\section{Organisational conflict}

Generally, it can be concluded that managers have to deal with a broad variety of organisational conflict in the described context. These conflicts are influenced by external realities such as globalisation trends (such as the South African headquarters depending on the mother company in Germany); national guidelines and policies for the organisation (such as guiding principles and the construction of a corporate national identity); as well as aspects of post-apartheid transitions (such as interlinking of cultural aspects and the fight for redistribution through formal organisational structures). At the same time, these organisational conflicts are created by 'cognitive-affective process dynamics' (Mischel \& Shoda, 1998, p. 229ff), such as thoughts, intentions, cognitive structures, feelings and emotions that impact on the conflict and its management, as shown in the excerpts from the narrations discussed in the previous section. Organisational conflict, therefore, needs to be assessed in the context of diverse influences that are shaped by managerial values and identities. This study focuses on the emic perspective of managers, referring to conflicts being mediated through the inner realities of the managers. It also ties to the Geertzian concept of 'webs of significance' and therefore to how managers are embedded in and influenced by multiple significant contextual layers:

man is an animal suspended in webs of significance he himself has spun, take culture to be those webs, and the analysis of it to be therefore not an experimental science in search of law, but an interpretative one in search of meaning.

(Geertz, 1973, p. 5)

TABLE 3

Overview of organisational conflicts

\begin{tabular}{|c|c|c|c|c|}
\hline$I^{1}$ & MANAGERIAL VALUES & IDENTITY ASPECTS & $\begin{array}{l}\text { CONFLICT MANAGEMENT } \\
\text { APPROACH }\end{array}$ & $\begin{array}{l}\text { MANAGERIAL VALUES AND } \\
\text { CONFLICT MANAGEMENT } \\
\text { APPROACH AND CONGRUITY } \\
\text { WITH ORGANISATIONAL GUIDING } \\
\text { PRINCIPLES }\end{array}$ \\
\hline P3:1 & $\begin{array}{l}\text { Transparency; truth; strong-mindedness; } \\
\text { corporate identity }\end{array}$ & $\begin{array}{l}\text { Work-related identity aspects, } \\
\text { strong identity based on strong- } \\
\text { mindedness }\end{array}$ & $\begin{array}{l}\text { Direct and honest communication; } \\
\text { support staff; mediation }\end{array}$ & $\begin{array}{l}\text { Value for customers and their } \\
\text { requirements; promote modern } \\
\text { organisational culture; promote } \\
\text { knowledge and experience of staff }\end{array}$ \\
\hline P4:1 & $\begin{array}{l}\text { Flexibility; authority; decision making by } \\
\text { authority; objectivity }\end{array}$ & $\begin{array}{l}\text { Strong conservative identity to cope } \\
\text { with personal challenges and injuries }\end{array}$ & $\begin{array}{l}\text { Compromise; consideration of all } \\
\text { interests; formal rules and procedures; } \\
\text { two-way communication }\end{array}$ & $\begin{array}{l}\text { Guided by principles of sustained yield; } \\
\text { respect for dignity of human beings }\end{array}$ \\
\hline P7:2 & $\begin{array}{l}\text { Co-operation; sharing of information; } \\
\text { ethics; racial and gender equality; } \\
\text { respect; adequate managerial conduct }\end{array}$ & Weakened, intimidated identity aspects & $\begin{array}{l}\text { Interaction and communication with, } \\
\text { and support from, the Board; } \\
\text { resignation }\end{array}$ & $\begin{array}{l}\text { Belief in fairness, tolerance and equal } \\
\text { opportunity; respect for dignity of } \\
\text { human beings }\end{array}$ \\
\hline P9:1 & $\begin{array}{l}\text { Trust; control; social networking; sharing } \\
\text { of information; 'open up files' }\end{array}$ & Identity shaken by conflict & Open and direct communication & $\begin{array}{l}\text { Promote knowledge and experience } \\
\text { among staff members }\end{array}$ \\
\hline $\mathrm{P} 13: 2$ & $\begin{array}{l}\text { Harmony; confidence; collaboration; } \\
\text { respect; honesty; join together to pursue } \\
\text { higher goals; corporate identity }\end{array}$ & Diplomatic and strong identity aspects & Team discussion; mediation & $\begin{array}{l}\text { Promote knowledge and experience } \\
\text { among staff members as most } \\
\text { important source; guided by principles } \\
\text { of sustained yield }\end{array}$ \\
\hline P19 & $\begin{array}{l}\text { Carrying out orders; } \\
\text { commitment towards organisation; } \\
\text { coping with work pressure; development } \\
\text { of joint interests of managers and staff } \\
\text { (corporate identity); achievement of good } \\
\text { results for the organisation }\end{array}$ & Strict and controlling identity & Control; correct behaviour & $\begin{array}{l}\text { Set attractive yield targets; guided by } \\
\text { principles of sustained yield }\end{array}$ \\
\hline P20 & $\begin{array}{l}\text { Co-operation; support throughout } \\
\text { weakness; confidence; truth and trustful } \\
\text { networking; trust and co-operation as } \\
\text { organisational values of corporate identity }\end{array}$ & Truth and harmony-based identity & $\begin{array}{l}\text { Structural changes to help avoid } \\
\text { mistakes }\end{array}$ & $\begin{array}{l}\text { Ensure tomorrow's success with } \\
\text { today's research and development; } \\
\text { guided by principles of sustained yield }\end{array}$ \\
\hline P32 & $\begin{array}{l}\text { Organisation comes first; work; } \\
\text { organisational rules; time management; } \\
\text { corporate identity; corporate } \\
\text { organisational rules and procedures; } \\
\text { personal integrity }\end{array}$ & Identity based on directness and clarity & Disciplinary hearing & \\
\hline P41 & $\begin{array}{l}\text { Time for decision making; stability in } \\
\text { management structures; accept rules and } \\
\text { procedures of organisation }\end{array}$ & $\begin{array}{l}\text { Identity concept shaken by intra- } \\
\text { personal conflict }\end{array}$ & Obedience to rules and procedures & \\
\hline
\end{tabular}

Source: Author's own construction 
Table 3 provides an overview of the narrated conflicts and the analysed aspects, which will be discussed with regard to recent literature.

The experience of conflict is not only an external reality, but rather a result of how each person perceives and approaches existing problems (Gaziano, Jensen-Campbell \& Hair, 1996) and therefore, at least in part, a result of 'cognitive-affective process dynamics' (Mischel \& Shoda, 1998, p. 251). Most of the managers mentioned that constructive conflict management needs inner distance or objectivity. The managers further asserted that negative personal feelings of hurt and anger do not contribute positively to conflict management in the organisation. The managers who succeeded in managing the conflict constructively (P3:1; P4:1; P9:1; P13:2; P19; P20 and P32) reconstructed and reinforced their managerial values through their way of conflict management and, therefore, contributed to the (re-)creation of aspects of the corporate identity.

Conflict in organisations, therefore, often relates to issues of identity and value and their priority, and may start when an individual or a group perceives differences and opposition between the self and the other about interests, beliefs, needs and values (De Dreu, Harinck \& Van Vianen, 1999), as analysed in the conflicts described in this and the previous section.

\section{Organisational conflict and managerial identity aspects}

This interplay of intra- and interpersonal conflict has been explored by many psychologists, who assume that the human mind consists of 'different parts in which the psyche, the value system and the behaviour is created' (Folger, Scott Poole \& Stutman, 2001, p. 45). This interdependence could also be seen in the interplay of the experienced organisational conflicts and the described aspects of the identities and values of the interviewed managers. According to Rahim (2002, p. 207), 'an interactive process does not preclude the possibility of intraindividual conflict, for it is known that a person often interacts with self'. In some cases, the inter-personal conflict was at the same time experienced as an intra-personal conflict (P7:2, P20). This interaction is also described as either a process of the 'many faces of a person' (Satir, 2001) or the communication of the 'inner team' (Schulz von Thun, 1998), in which outer experiences are transformed into inner voices that reconstruct both the multiple identity aspects, and the internal and external realities of a person. It is apparent, therefore, that conflict relates to aspects of identity or even forms part of identity and this, in turn, can lead to 'identity crisis' (Mayer, 2005). In these two narrated conflict situations (P7:2, P20), the managers also reconstructed parts of their identities and their inner voices according to the inter-personal conflict experienced and felt deeply irritated with regard to their individual identity concept.

Aspects of the identity of managers are viewed as important aspects of organisational conflict and its management across managerial and organisational levels (Humphreys \& Brown, 2002), as described in the conflict narrations. The managers felt that they were influenced by different identity aspects, which are interlinked and which may be compared to the concept of 'patchwork identity' (Keupp, 1988) discussed previously. In most of the cases evaluated, the conflict experienced and multiple identity aspects led either to a re-creation of identity and values or to an 'identity and value crisis'.

Four managers highlighted that they felt strong in and strengthened by the conflict they experienced and that they were guided by aspects of their strong identity, which opened up ways to manage the conflict constructively (P3:1, P4:1, P3:2, P20). Five managers highlighted their shaken identity, their irritation and the weakening of their identity (concept). These impacts on identity aspects were experienced as negative and as causing tension, leading to a type of individual 'identity crisis' (Maringer \& Steinweg, 1997)

\section{Organisational conflict and managerial values}

Values are viewed as aspects that interlink individual and organisational management levels in organisations, particularly in the fields of management, leadership and organisational studies (Humphreys \& Brown, 2002), and which further represent aspects of the organisational culture (Schein, 2004). They have a major, underlying impact on conflict and its management (Moore, 1996) - as shown in this case study - as they are essentially dialectic and contradictory (Gandal et al., 2005; Smith et al., 2002; Stewart, Danielian \& Foster, 1998). Furthermore, conflict management often relates to the negotiation and management of values (Berkel, 2005; Wallace et al., 1999). Clashing value concepts are common in diverse settings (Miller, Glen, Jaspersen \& Karmokolias, 1997) and are further interlinked with the cultural background of a person (Kitayama \& Markus, 1991), as highlighted above.

The research results from this case study indicate that organisational conflict and value orientations, and the management thereof, often relate to aspects of individual managerial perceptions. The managers linked their individual managerial values with the quest for the corporate identity (P3:1, P13:2, P19, P20 and P32). In some cases, the managers wished to promote their individual managerial values - particularly with regard to the concepts of truth, honesty, information sharing, working and joining together for higher goals - as part of the corporate identity of the organisation. In this organisational case study, therefore, values contribute to the organisational culture.

Managing conflict in organisations should include 'cutting across cultures' (Burton, 1990, pp. 211-212) and values, even if there are culturally defined means of dealing with conflict (Horowitz, 1985). Post-apartheid South Africa is on its way to managing and reconciling differences with regard to language, culture and values (Moodley \& Adam, 2000; Slabbert, 2001). Thomas and Bendixen (2000) suggest that international organisational and management contexts in South Africa promote diversity through management effectiveness and an inclusive organisational culture. According to Schein (2004), a 'set of values that become embodied in an organizational philosophy can serve as a guiding principle toward managing conflicts or difficult events'. It has been established (Druckmann, Broom \& Korper, 1988) that parties are generally more willing to move further from their initial position and become more cooperative when they have talked about value orientations before negotiations. However, this could not be estimated in this study and needs to be researched further.

\section{Managing organisational conflict from the manager's viewpoint}

Managing aspects of structural and operational organisational conflict and value orientations lies in the area of tension regarding individual managerial values. These are perceived as being unfulfilled in the described conflicts (truth, honesty, transparency, harmony) and in the guiding principles that form part of the corporate identity values (such as the endeavour for equality of all levels, respectful and fair mutual treatment). In some cases, the managerial values are congruent with the guiding principles with regard to the corporate identity of the organisation, as shown in Table 3 . In most of the instances of organisational conflict experienced, however, the guiding principles of the organisation did not meet the managers' needs for values and guidance.

With regard to the limitations of this study, it needs to be mentioned that it cannot be generalised and thereof only gives answers to very concrete research questions with regard to the context described. It also does not reach a theoretical level, but stays at the practical level of describing conflict, values and identities in the selected organisation. The recommendations that can be made follow below. 


\section{Recommendations}

With regard to recent literature on conflict, values, identities and their management, and the results of this research, the challenge for international human resource management in international organisations in South Africa lies in the construction of a corporate identity that cares for the diverse interests, identity aspects and value orientations of the different parties, and the levels involved: the international level, with regard to cooperation between the German and South African headquarters; the national level, with regard to the guidelines and principles for the national organisation; and the local level, including individual managerial perceptions, values and identities. The challenge for the selected organisation is in the transformation of organisational structures that support:

- managerial competencies, which support direct and open communication as well as regular exchange of ideas, thoughts and feelings on conflict;

- informal and alternative conflict management strategies, such as the implementation of non-violent communication trans-cultural mediation, team discussions and sharing sessions, which also address issues of identity and values;

- the implementation of working and coaching sessions on identity with managers, focussing on the development of a congruent managerial identity that aims at conflict management practices. This work on identity should include the strengthening of positive identity aspects and individual resources in managers, and their reflection in the corporate culture of the organisation, as well as the promotion of constructive conflict management practices that are connected to the managerial identity and values;

- reflection of the value orientations and value priorities of the managers in their different roles as team members, subordinates and superiors, and in actively constructing the corporate culture of the organisation (human resource development and individual managerial development); and

- active engagement to transform and influence structural and operational processes, globalisation trends, national guidelines and post-apartheid structures in a non-violent and constructive way.

The transformation of these aspects in the organisation could lead to a reduction in organisational conflict potential and could, therefore, create synergies which might lead to the improvement of human resource and conflict management in the organisation. The (re-)construction of managers' identities through work on their identity and particularly through managerial coaching is a major source of success in individual and organisational (conflict) management. The understanding of the complex (managerial) identity constructions from an emic perspective can lead to creative spaces and synergies in a diverse organisation. It can further help to develop an awareness of multiple identities and process synergies across managerial and departmental lines. Professional human resource management, with regard to identity and value, will then lead to an improvement in organisational strategies and organisational integrity, and successful identity-based diversity and conflict management.

Finally, based on the outcome of this research and the limitation of not being about to make generalisations from this case study on a single organisation, the following can be recommended for future research on organisational conflict in South Africa:

- to replicate this study in a couple of different international organisations based in South African to gain deeper insight into and understanding of a culture-specific point of view;

- to conduct a study on conflict, identities and values in a different South African (work) context to gain a broader view of these issues in the South African society;

- to replicate this study within this organisation in different countries to gain insight into culture-specific and / or culturegeneral issues of conflict, identities and values in different national cultures in one international organisation within a global context; and
- to develop a study on the abovementioned topics of conflict, values and identity by using qualitative and quantitative research approaches to deepen and widening the focus of research.

\section{REFERENCES}

Albert, S., Ashforth, B., \& Dutton, J. (2000). Special topic forum on organizational identity and identification. Academy of Management Review, 25(1), 13-152.

Alvesson, M. (2000). Social identity and the problem of loyalty in knowledge-intensive companies. Journal of Management Studies, 37(8), 1101-1123.

Antonioni, D. (1998). Relationship between the big five personality factors and conflict management styles. International Journal of Conflict Management, 9(4), 336-355.

Applefield,J.M.,Huber, R., \& Moallem, M. (2000). Constructivism in theory and practice: Toward a better understanding. The High School Journal, 84(2), 35-53.

Augsburger, D.W. (1992). Conflict mediation across cultures. Kentucky: John Knox Press.

Avruch, K. (1998). Culture and conflict resolution. Washington: USIP Press.

Becvar, D.S., \& Becvar, R.J. (2006). Family therapy: A systemic integration. (6th edn.). Boston: Allyn \& Bacon.

Berger, P.L., \& Luckmann, T. (2000). Die gesellschaftliche Konstruktion der Wirklichkeit. Eine Theorie der Wissenssoziologie [The societal construction of reality]. (17th edn.). Frankfurt: Fischer.

Berkel, K. (2005). Wertkonflikte als Drama - Reflexion statt Training [Value conflicts as drama - reflection instead of training]. Wirtschaftspsychologie. Themenheft Konfliktprozesse in der betrieblichen Lebenswelt - Theorie, Konzepte, Pragmatik, $4(1), 2-8$

Bornman, E. (2003). Struggles of identity in the age of globalization. Communication - South African Journal of Communication Theory and Research, 29(1\&2), 24-47.

Burton, J.W. (1990). Conflict: Human needs theory. London: Macmillan.

Cheldelin, S., Druckman, D., \& Fast, L. (2003). Conflict: From analysis to intervention. New York: Continuum.

Church, A. (1995). Diversity in work-group setting: A case study. Leadership and Organizational Development Journal, 16(6), 3-9.

Coleman, P.T. (2003). Characteristics of protracted, intractable conflict: Toward the development of a metaframework. Peace and Conflict: Journal of Peace Psychology, 9(1), 1-37.

Collis, J., \& Hussey, R. (2003). Business research: A practical guide for undergraduate and postgraduate students. (2nd edn.). New York: Palgrave Macmillan.

Cowan, D. (1995). Taking charge of organizational conflict: A guide to managing anger and confrontation. Spring Valley: Inner Choice Publishing.

Coy, P.G., \& Woehrle, L.M. (2000). Social conflicts and collective identities. New York: Rowman \& Littlefield.

De Anca, C., \& Vega, A.V. (2006). Managing diversity in the global organization. Creating new business values. New York: Palgrave Macmillan.

De Dreu, C.K.W., Harinck, F., \& Van Vianen, A.E.M. (1999). Conflict and performance in groups and organizations. In C.L. Cooper \& I.T. Robertson (Eds.), International review of industrial and organizational psychology (p. 14). Chichester: Wiley.

Demmers, J. (2006). Conflict research: Lacunas, mantras and pitfalls. ISYP Journal on Science and World Affairs, 2(2), 99102.

Dickerson, V.C., \& Zimmerman, J.L. (1996). Myths, misconceptions, and a word or two about politics. Journal of Systemic Therapies, 15(1), 79-88.

Druckmann, D., Broom, B.J., \& Korper, S.H. (1988). Value differences and conflict resolution: Facilitation or delinking? Journal of Conflict Resolution, 32(3), 234-251. 
Dutton J., Dukerich, J., \& Harquail, C. (1994). Organizational images and member identification. Administrative Science Quarterly, 39, 239-263.

Folger, J.P., Scott Poole, M., \& Stutman, R.K. (2001). Working through conflict: Strategies for relationships, groups and organizations. (2nd edn.). New York: Addison Wesley Longman.

Francesco, A.M., \& Gold, B.A. (2005). International organizational behaviour. (2nd edn.). New Jersey: Pearson Prentice Hall.

Francis, D. (2003). People, peace and power: Conflict transformation in action. Peace Review, 15(2), 241-243.

Fryzel, B. (2004). Values and knowledge creation. A study on diversity management. International Journal of Knowledge, Culture and Change Management, 4. Retrieved September 9, 2008, from http://ijm.cgpublisher.com/product/pub.28/ prod.4.54

Gandal, N., Roccas, S., Sagiv, L., \& Wrzesniewski, A. (2005). Personal value priorities of economists. Human Relations, 58(10), 1227-1252.

Garcia-Prieto, P., Bellard, E., \& Schneider, S.C. (2003). Experiencing diversity, conflict, and emotions in teams. Applied Psychology (special issue on workforce diversity in the international context), 52(3), 413-440.

Gaziano, W.G., Jensen-Campbell, L.A., \& Hair, E. (1996). Perceiving interpersonal conflict and reacting to it: The case of agreeableness. Journal of Personality and Social Psychology, 70(4), 820-835.

Geertz, C. (1973). The interpretation of cultures. New York: Basic Books.

Geertz, C. (1987). Dichte Beschreibung. Beiträge zum Verstehen kultureller Systeme [Thick descriptions. Contribution to understand cultural systems]. Frankfurt: Suhrkamp.

Ghai, Y.P., Bloomfield, D., \& Reilly, B. (1998). Analysing deeprooted conflict. In P. Harris \& P. Reilly (Eds.), Democracy and deep-rooted conflict: Options for negotiations (pp. 3148). Stockholm: Institute for Democracy and Electoral Assistance.

Gioia, D., Schultz, M., \& Corley, K. (2002). On celebrating the organization identity metaphor: A rejoinder to Cornelissen. British Journal of Management, 13, 269-275.

Gobeli, D.H., Koenig, H.F., \& Bechinger, I. (2003). Managing conflict in software development teams: A multilevel analysis. Journal of Product Innovation Management, 15(5), 423-435.

Gonzalez, N., Moll, L.C., Floyd-Tenery, M., Rivera, A., Rendon, P., Gonzales, R. et al. (1994). Funds of knowledge: Learning from language-minority households. ERIC Digest. Retrieved July 19, 2008, from http://www.ericfacility.net/databases/ ERIC_Digests/ed367146.html

Habermas, J. (1999). Theorie des Kommunikativen Handelns [Theory of the communicative action]. (3rd edn.). Frankfurt: Suhrkamp.

Harris, H., Brewster, C., \& Sparrow, P. (2003). International human resource management. London: CIPD.

Hatch, M., \& Schulz, M. (2002). The dynamics of organizational identity. Human Relations, 55(8), 989-1018.

Hiltrop, J.M., \& Partner, S. (1996). The impact of human resource management on organizational performance: Theory and research. European Management Journal, 14(6), 628-637.

Hipps, J.A. (1993, April). Trustworthiness and authenticity: Alternate ways to judge authentic assessments. Paper presented at the annual meeting of the American Educational Research Association, Atlanta, GA.

Horowitz, D.L. (1985). Ethnic groups in conflict. California: University of California Press.

Horwitz, F.M., Bowmaker-Falconer, A., \& Searll, P. (1996). Human resource development and managing diversity in South Africa. International Journal of Manpower, 17(4/5), 134-151.

Human, L. (1996). Managing workforce diversity: A critique and example from South Africa. International Journal of Manpower, 17(4/5), 46-64.
Humphreys, M., \& Brown, A. (2002). Narratives of organizational identity and identification: A case study of hegemony and resistance. Organization Studies, 23, 421-427.

Jackson, T. (1999). Managing change in South Africa: Developing people and organizations. International Journal of Human Resource Management, 10(2), 306-326.

Jackson, T. (2002). The management of people across cultures: Valuing people differently. Human Resource Management, 41(4), 455-475.

Jehn, K.A. (1997). The qualitative analysis of conflict types and dimensions in organizational groups. Administrative Sciences Quarterly, 42(3), 530-557.

Johnson, B.R. (1997). Examining the validity structure of qualitative research. Education, 118(3), 282-292.

Jonassen, D.H. (1991). Evaluating constructivistic learning. Educational Technology, 28(11), 13-16.

Jones, G.R., \& George, J.M. (2003). Contemporary management. (3rd edn.). New York: McGraw-Hill.

Kamoche, K. (1997). Managing human resources in Africa: Strategic, organizational and epistemological issues. International Business Review, 6(5), 537-558.

Kamoche, K. (2002). Introduction: Human resource management in Africa. International Journal of Human Resource Management, 13(7), 993-997.

Kandola, R. (1995). Managing diversity: New broom or old hat? International Review of Industrial and Organizational Psychology, 10(3), 131-167.

Keupp, H. (1988). Auf dem Weg zur Patchwork-Identität [On the way to a patchwork identity]. Verhaltenstherapie and Psychosoziale Praxis. Mitteilungen der dgvt, 4(88), 425-438.

Keupp, H. (1994). Ambivalenzen postmoderner Identität [Ambivalences of post-modern identity]. In U. Beck \& E. Beck-Gersheim (Eds.), Riskante Freiheiten. Individualisierung in modernen Gesellschaften (pp. 336-350). Frankfurt: Suhrkamp.

Keupp, H. (1997). Von der (Un-)Möglichkeit erwachsen $\mathrm{zu}$ werden - Jugend zwischen Multioptionalität und Identitätsdiffusion [The (im-)possibility of becoming an adult - Youth between multi-optionality and identity diffusion]. Gemeindepsychologie-Rundbrief, 1(97), 10-15.

Kitayama, S., \& Markus, H.R. (1991). Culture and the self: Implications for cognition, emotion and motivation. Psychological Review, 98(2), 224-253.

Kluckhohn, F.R., \& Stroedbeck, F.L. (1961). Variations in value orientations. Evanston: Row, Peterson and Company.

Kriesberg, L. (2003a). Constructive conflicts: From escalation to resolution. (2nd edn.). New York: Rowman \& Littlefield.

Kriesberg, L. (2003b). Identity issues. In G. Burgess \& H. Burgess (Eds.), Beyond intractability. Retrieved July 22, 2008, from http://www.beyondintractability.org/m/identity_issues. jsp

Kriesberg, L. (2003c). Factors shaping the course of intractable conflict. In G. Burgess \& H. Burgess (Eds.), Beyond intractability. Retrieved July 22, 2008, from http://www. beyondintractability.org/m/factors_shaping_intractable_ conflict.jsp

Kromrey, H. (1998). Empirische Sozialforschung [Empiric social research]. (8th edn.). Opladen: Leske und Budrich.

Lederach, J.P. (1988). Of nets, nails and problems: A folk vision of conflict in Central America. Unpublished dissertation, University of Colorado, Colorado, USA.

Lederach, J.P. (1996). Preparing for peace. Conflict transformation across cultures. New York: Syracuse University Press.

Lederach, J.P. (2000). The cultural dimension. Akron: Mennonite Conciliation Service.

Lederach, J.P. (2005). All conflicts are identity conflicts. In G. Burgess \& H. Burgess (Eds.), Beyond intractability. Retrieved November 6, 2007, from http://www.beyondintractability. org/user_guides/identity_conflict/?nid=5306

Lindgren, M., \& Wåhlin, N. (2001). Identity construction among boundary-crossing individuals. Scandinavian Journal of Management, 17(3), 357-377. 
Maringer, E., \& Steinweg, R. (1997). Konstruktive Haltungen und Verhaltensweisen in institutionalisierten Konflikten. Erfahrungen, Begriffe, Fähigkeiten [Constructive attitudes and behaviour. Experiences, terms, skills]. Berlin: Berghof Forschungszentrum für konstruktive Konfliktbearbeitung.

Martin, J. (2002). Organizational culture: Mapping the terrain. Thousand Oaks: Sage.

Mayer, B. (2000). The dynamics of conflict management: A practitioner's guide. San Francisco: Jossey-Bass.

Mayer, C.-H. (2005). Artificial walls. South African narratives on conflict, difference and identity. An exploratory study in postapartheid South Africa. Stuttgart: Ibidem.

Mayer, C.-H. (2008a). Managing conflict across cultures, values and identities. A case study in the South African automotive industry. Marburg: Tectum.

Mayer, C.-H. (2008b). Identity and health in transcultural mediation. The model of Culture-Synergetic Transcultural Mediation and its impacts. Journal of Intercultural Communication, 17. Retrieved 28 June, 2008, from http:// www.immi.se/intercultural/

Mayer, C.-H., \& Louw, L. (2007). Management of transcultural conflicts: A case study in the South African automotive industry. In Proceedings of the South African International Management Science (SAIMS) Conference, 19-21 October 2007. Johannesburg, Gauteng, South Africa. Retrieved September 27, 2007, from http://www.uj.ac.za/saims2007/Track\%20 12/12Mayer_Track12_CP.pdf

Mayring, P. (2003). Qualitative Inhaltsanalyse [Qualitative content analysis]. (8th edn.). Weinheim: Beltz Verlag.

McLeod, J. (1996). The emerging narrative approach to counselling and psychotherapy. British Journal of Guidance $\mathcal{E}$ Counselling, 24(2), 173-195.

Miall,H.,Ramsbotham,O., \&Woodhouse, T.(2000). Contemporary conflict resolution. Cambridge: Polity Press.

Miller, R., Glen, J., Jaspersen, F., \& Karmokolias, Y. (1997) International joint ventures in developing countries. Finance and Development, 29(3), 10-26.

Mischel, W., \& Shoda, Y. (1998). Reconciling processing dynamics and personality dispositions. Annual Review of Psychology, 43(3), 229-258.

Moodley, K., \& Adam, H. (2000). Race and nation in postapartheid South Africa. Current Sociology, 48(3), 51-69.

Moore, C.W. (1996). The mediation process. Practical strategies for resolving conflict. (2nd edn.). San Francisco: Jossey-Bass.

Mujtaba, B.G. (2006). Workforce diversity management challenges, competencies and strategies. Tamarac: Llumina Press.

Mullins, L.J. (2007). Management and organizational behaviour. (8th edn.). London: Prentice Hall.

Nel, P.S., Van Dyk, P.S., Haasbroek, G.D., Schultz, H.B., Sono, T., \& Werner, A. (2004). Human resource management. (6th edn.) Cape Town: Oxford University Press.

Northrup, T.A. (1989). The dynamic of identity in personal and social conflict. In L. Kriesberg, T.A. Northrup \& S.J. Thorson (Eds.), Timing the de-escalation of international conflict (pp. 55-82). Syracuse: Syracuse University Press.

Nye, J.S. (2005). Understanding international conflicts. An introduction to theory and history. (5th edn.). New York: Longman.

Organizational Paper. (2002a). [Employment equity and affirmative action policy]. Unpublished internal paper.

Organizational Paper. (2002b). [Grievance procedure]. Unpublished internal paper.

Organizational Paper. (2006a). [Annual report, 2005]. Unpublished internal paper.

Organizational Paper. (2006b). [Company truck and bus Southern Africa. Company profile 2005]. Unpublished internal paper.

Overman, S. (1991). Managing the diverse workforce. HR Magazine, 36(3), 32-36.

Pondy, L.R. (1992). Reflections on organizational conflict. Journal of Organizational Behaviour, 13(2), 257-261.
Pool, S.W. (2000). Organizational culture and its relationship between job tension in measuring outcomes among business executives. Journal of Management Development, 19(1), 32-49.

Pratt, M., \& Rafaeli, A. (1997). Organizational dress as a symbol of multilayered social identities. Academy of Management Journal, 40(4), 862-898.

Rahim, M.A. (2001). Managing conflict in organizations. (3rd edn.). Westport: Quorum Books.

Rahim, M.A. (2002). Toward a theory of managing organizational conflict. The International Journal of Conflict Management, 13(3), 206-235.

Ricoeur, P. (1979). Der Text als Modell: Hermeneutisches Verstehen [The text as model: Hermeneutic understanding]. In W.L. Bruehl (Ed.), Verstehende Soziologie. Grundzuege und Entwicklungstendenzen. München: Nymphenburger Verlag.

Satir, V. (2001). Meine vielen Gesichter - Wer bin ich wirklich? [My many faces - Who am I really?]. München: Kösel Verlag.

Schein, E. (2004). Organizational culture and leadership. (3rd edn.). San Francisco: Jossey-Bass.

Schulz von Thun, F. (1998). Miteinander reden 3 - Das Innere Team und situationsgerechte Kommunikation. [Talking with each other - The inner team and situation adequate communication]. Reinbek: Rowohlt Taschenbuchverlag.

Schwartz, S.H., \& Bardi, A. (2001). Value hierarchies across cultures taking a similarities perspective. Journal of CrossCultural Psychology, 32(3), 268-290.

Schwartz, S.H., Melech, G., Lehmann, A., Burgess, S., Harris, M \& Owens, V. (2001). Extending the cross-cultural validity of the theory of basic human values with a different method of measurement. Journal of Cross-Cultural Psychology, 32(5), 519-542.

Shonhiwa, S. (2006). The effective cross-cultural manager. A guide for business leaders in Africa. Cape Town: Zebra Press.

Slabbert, A. (2001). Cross-cultural racism in South Africa - dead or alive? Social Behavior and Personality: An International Journal, 29(2), 125-132.

Smith, P.B., Peterson, M.F., \& Schwartz, S.H. (2002). Cultural values, sources of guidance, and their relevance to managerial behaviour. A 47-nation study. Journal of CrossCultural Psychology, 33(2), 188-208.

Sparrow, P.-R., \& Hiltrop, J.M. (1997). Redefining the field of European human resource management: A battle between national mindsets and forces of business transition? Human Resource Management, 36(2), 201-219.

Stake, R.E. (2005). Qualitative research studies. In N.K. Denzin \& Y.S. Lincoln (Eds.), The Sage handbook of qualitative research (pp. 443-467). Thousand Oaks: Sage.

Stellrecht, I. (1993). Interpretative Ethnologie: Eine Orientierung [Interpretative ethnology: An orientation]. In T. Schweizer, M. Schweizer \& W. Kokot (Eds.), Handbuch der Ethnologie (pp. 29-73). Berlin: Reimer.

Stewart, E.C., Danielian, J., \& Foster, R. (1998). Cultural assumptions and values. In M.J. Bennett (Ed.), Basic concepts of intercultural communication. Selected readings (pp. 157-172). Maine: Intercultural Press.

Strauss, A.L. (1987). Qualitative analysis for social scientists. Cambridge: Cambridge University Press.

Sveningsson, S., \& Alvesson, M. (2003). Managing managerial identities: Organizational fragmentation, discourse and identity struggle. Human Relations, 56(10), 1163-1193.

Terre Blanche, M., Durrheim, K., \& Kelly, K. (2006). First steps in qualitative data analysis. In M. Terre Blanche, K. Durrheim \& D. Painter (Eds.), Research in practice. Applied methods for the social sciences (pp. 321-344). Cape Town: University of Cape Town.

Thomas, A., \& Bendixen, M. (2000). The management implications of ethnicity in South Africa. Journal of International Business Studies, 31(3), 507-519.

Voelpel, S.C., Leibold, M., \& Tekie, E.B. (2006). Managing purposeful organizational misfit: Exploring the nature of industry and organizational misfit to enable strategic change. Journal of Change Management, 6(3), 257-276. 
Von Steinke, I. (2000). Gütekriterien qualitativer Forschung [Criteria of qualitative research]. In U.V. Flick, E. Kardoff \& I. von Steinke (Eds.), Qualitative Forschung. Ein Handbuch (pp. 219-331). Hamburg: Rowohlts Enzyklopädie.

Wallace, J., Hunt, J., \& Richards, C. (1999). The relationship between organizational culture, organizational climate and managerial values. International Journal of Public Sector Management, 12(7), 548-564.

Webster, E., \& Adler, G. (1999). Towards a class compromise in South Africa's "double transition". Bargained liberalization and the consolidation of democracy. Politics and Society, $27(3), 347-385$.
Whetten, D., \& Godfrey, P. (1998). Identity in organizations. Sage: London.

Wolff, S. (2000). Clifford Geertz. In U. Flick, E. Kardoff \& I. von Steinke (Eds.), Qualitative Forschung. Ein Handbuch [Qualitative research. A handbook.] (pp. 84-96). Hamburg: Rowohlts Enzyklopädie.

Wood, G., \& Mellahi, K. (2001). Human resource management in South Africa. In S. Pawan, A. Budhwar \& S. Debrah (Eds.), Human resource management in developing countries (pp. 222237). London: Routledge.

Yin, R.K. (2002). Case study research: Design and methods. (2nd edn.). London: Sage. 